\title{
The Rise of the Gendarmes? What Really Happened in Holland
}

\section{Michiel de Weger*}

The military and the police share more than 150 years of history. ${ }^{1}$ Before the mid-nineteenth century, no country in the world had a police organization like those that are found in modern Western societies today. It is a widely held belief that the civilian police was created to take the task of maintaining public order-particularly in urban areas - out of the hands of the military, because they tended to use excessive violence. ${ }^{2}$ As the number of civilian police organizations in Western countries increased over the decades, and as they gained strength and their roles expanded, the military slowly "disappeared" from cities, and from public life in general. The police were "emancipated" from the military. This process is still going on, and can be expected to continue in the foreseeable future.

Gendarme forces are a fascinating phenomenon, in that they act as intermediaries between regular, civilian police forces and the military. A legacy of the Napoleonic occupation of half of the European continent and the period of colonization, this kind of military police force is found in many countries. The following countries have gendarme forces with 4,000 or more personnel: Algeria, Argentina, Austria, Cameroon, Canada, Chile, France, Italy, Ivory Coast, Morocco, the Netherlands, Portugal, Romania, Senegal, Spain, Chad, Tunisia, Turkey, and Venezuela. ${ }^{3}$ Studying military police

* Dr. Michiel de Weger is a researcher at the Royal Netherlands Defense Academy. He can be reached at MJ.d.Weger@nlda.nl.

1 See, for example, Clive Emsley, Gendarmes and the State in Nineteenth-Century Europe (Oxford: Oxford University Press, 1999); David Adams, "Internal Military Intervention in the United States,” Journal of Peace Research 32:2 (1995): 197-211; Peter J. Rowe and Christopher J. Whelan, eds., Military Intervention in Democratic Societies (London: Croom Helm, 1985); Cyrille Fijnaut, Opdat de Macht een Toevlucht Zij?: Een Historische Studie van het Politieapparaat als een Politieke Instelling (Arnhem: Gouda Quint, 1979); David E. Engdahl, "Soldiers, Riots, and Revolution: The Law and History of Military Troops," Iowa Law Review 57:1 (October 1971): 1-73; and David H. Bayley, “The Police and Political Development in Europe,” in The Formation of National States in Western Europe, ed. Charles Tilley (Princeton, NJ: Princeton University Press, 1975), 328-79.

2 See Larry L. Watts, "Whose Professionalism?: Separating the Institutional Roles of the Military and Police” (Camberley: Conflict Studies Research Centre, November 2001); Philip Rawlings, “The Idea of Policing: A History,” Policing and Society 5 (1995): 129-49; Robert T. Sigler and David J. King, "Colonial Policing and Control of Movements for Independence,” Policing and Society 3 (1992): 13-22; William W. Miller, "Party Politics, Class Interest, and Reform of the Police 1829-56,” Police Studies (1987): 42-60; James H. Auten, “The Paramilitary Model of Police and Police Professionalism,” Police Studies 4 (1981): 6778; and Clive Emsley, Policing and its Context, 1750-1870 (London: Macmillan, 1983).

3 Cees N.J. Neisingh, “Zusterkorpsen van de Koninklijke Marechaussee,” Armex (February 1998): 22-25. 
in these countries can provide valuable insight into their national "security complexes." 4

What do we know about the role and function of gendarme forces? Relatively little scientific attention has been paid to these hard-to-understand military police organizations. There is little literature on their tasks; on how they relate to military and civilian authorities and cooperative partners; their (dis)similarities with the police and the military; their (colonial) history and current challenges; or on their role in domestic security and peacekeeping operations abroad. Many scholars have addressed individual, national gendarme forces, ${ }^{5}$ but few of these studies involve either international comparison or theory.

The aim of this article is to improve our theoretical understanding of gendarme forces. To this end, I first describe what the literature tells us about their function. I compare this to the gendarmerie with which I am most familiar, the Royal Marechaussee in the Netherlands. After summarizing the findings of a study of the Royal Marechaussee, I advance several original hypotheses regarding gendarme forces and make a number of suggestions for further research.

\section{Some Thoughts from the Literature}

The scholarly literature on policing offers a broad array of seemingly unrelated remarks or theses about gendarmerie or, as these entities are often called, paramilitary organizations. Writing about the recent history of developing nations, Janowitz states that the growth of paramilitary forces "contributes to regime stability, because of the increased resources at the disposal of the groups in power." These forces are "instruments for controlling unrest and mob action," for the "continuous task of policing the potentially disruptive groupings of resistance or opposition to the central regime - regional, religious, or ethnic minorities who feel excluded from the existing political arrangements." According to Janowitz, the growth of paramilitary units is a worldwide trend. ${ }^{6}$

Deflem states that police institutions tend to become aligned (or re-aligned) with the military during periods of war. Policing tasks expand to include new tasks inti-

4 A term used in Leo W. J. C. Huberts, Blinde Vlekken in de Politiepraktijk en de Politiewetenschap - Over Politie, Wetenschap, Macht, Beleid, Integriteit en Communicatie (Arnhem: Gouda Quint, 1998).

5 For instance, see W. van den Hoek, De Geschiedenis van het Wapen der Koninklijke Marechaussee (Buren: Museum der Koninklijke Marechaussee, 1990); Hubert Haenel, René Pichon, and Richard Lizurey, La Gendarmerie (Paris: Presses Universitaires, 1983); the special issue of Les Cahiers de la Sécurité Intérieure (no. 11, 1992) which contains chapters on (historical) gendarmerie in Brazil, Canada, Chile, France and Spain; Marleen Easton, De Demilitarisering van de Rijkswacht (Brussels: VUB Press, 2001); and Adrianus Meliala, "Police as Military: Indonesia's Experience," Policing: An International Journal of Police Strategies and Management 24:3 (2001): 420-31.

6 Morris Janowitz, Military Institutions and Coercion in Developing Nations (Chicago: University of Chicago Press, 1977), 7, 41, 45. 
mately related to the war effort, and police forces often receive new and improved equipment, personnel, and budgets. All of these changes are rescinded once peace has been established. ${ }^{7}$ As intermediaries between the regular police and the military, gendarmes are the most likely candidates for such processes of alignment and separation.

Hills paints a similar picture of police forces during low-intensity conflicts. While normal police functions nearly cease, the focus reverts to the paramilitary, regulatory (i.e., border control), and representative components of policing functions. After a conflict has ended, the reconstruction of the police becomes a priority, "partly because it can neutralize violence or military activities comparatively cheaply.",

Writing about the utility of the French Gendarmerie, the Italian Carabinieri, and similar forces in peacekeeping operations, Schmidl contends that, because of their tasks at home, these organizations should be regarded as police forces rather than as gendarme or paramilitary forces, even though they were created in the nineteenth century to fill the same security gap at home that they currently fill in operations abroad. ${ }^{9}$

\section{Lutterbeck}

Derek Lutterbeck, a researcher at the Geneva Centre for Security Policy, is probably the most interesting author on the position of gendarme forces within the present security environment. His doctoral thesis and his article on the "rise of the gendarmes," which is based on his thesis, contain many ideas about the role of these forces in national and international security. ${ }^{10}$

In the article, Lutterbeck refers to the growth in numbers of personnel and equipment within gendarme forces, as well as to their relevance for current security challenges. Lutterbeck specifically identifies border patrol and international peacekeeping operations as the main areas of growth, presenting statistics from the gendarmeries (and other national security forces) of various countries, covering more than a decade. Between 1989 and 2000, the German Federal Border Police doubled in personnel size (by way of comparison, the number of state police in Germany grew by 4 percent between 1990 and 1997), and its budget nearly tripled. The number of personnel in the Austrian gendarmerie increased by one-third between 1990 and 2000, and the budget increased by two-thirds (the Austrian Federal Police, in contrast, remained constant in size and received a budget increase of only 12 percent). In Italy, the budget of the

Mathieu Deflem, Policing World Society: Historical Foundations of International Police Cooperation (Oxford: Oxford University Press, 2002), 120.

8 Alice Hills, "Policing, Enforcement and Low Intensity Conflict," Policing and Society 7:4 (1997): 291-308.

9 Erwin Schmidl, "Police Functions in Police Operations," in Policing the New World Disorder: Peace Operations and Public Security, ed. Robert B. Oakley, Michael J. Dziedzic, and Eliot M. Goldberg (Washington, D.C.: National Defense University Press, 1998), 40.

10 Lutterbeck's 2003 thesis in political science has apparently never been published commercially, and is therefore available only on loan from the Graduate Institute of International Studies in Geneva. The article that draws on the ideas set forth in the dissertation is: Derek Lutterbeck, "Between the Police and Military: The New Security Agenda and the Rise of the Gendarmeries,” Cooperation and Conflict 39:1 (2004): 45-68. 
Guardia di Finanza tripled between 1989 and 2000 (the budget of the State Police only doubled), while its naval services gained 45 percent more personnel. Between 1990 and 2000, the number of boats and aircraft (helicopters and airplanes) in the naval services of the Spanish Guardia Civil increased six-fold, and doubled for its air services. The overall personnel size of this force grew by only about 15 percent, but its budget increased by 50 percent. The U.S. Border Patrol doubled its personnel between 1990 and 2001. ${ }^{11}$

Against this background of the growing scale and importance of gendarmerie organizations, Lutterbeck advances the following theses concerning the historical development of gendarme forces:

- "With the emergence of the modern nation-state, the armed forces have gradually been removed from the state's domestic sphere."12

- "Over time, all of these forces, or their descendants, have undergone a process of 'demilitarisation,' in that their military characteristics have been attenuated and their links to the armed forces severed."13

- $\quad$ The gendarmerie is usually responsible for maintaining law and order in rural areas ....[its] duties tend to include those types of threats or situations which are characterised by a higher degree of hostility or 'instability' than 'ordinary' policing usually involves ... they are also often associated with authoritarian or repressive tendencies, and seen as an at least potential threat to civil liberties." 14

- "The main driving force behind this development has been a growing concern with various transnational challenges, ranging from irregular migration and drug trafficking to international terrorism, and the perceived need to upgrade state borders and close them to these 'undesirables.",15

- "In particular the task of monitoring green (i.e., land) and blue (sea) borders require heavier equipment than civilian-style police forces usually have, such as airplanes, helicopters, and high-speed patrol boats." 16

- "Typical internal security tasks arising in peace-building missions, such as crowd control, combating organised crime, or protecting refugees, of course require policing skills and equipment. ... On the other hand, given the often high level of instability in which such operations unfold ... the more robust nature of gendarmerie or paramilitary forces, and their ability to operate in hostile environments is also seen as a crucial asset. ... The growing popularity

11 Lutterbeck, "Between the Police and Military,” 52-57.

12 Ibid., 46-47.

13 Ibid., 47.

14 Ibid., 50.

15 Ibid., 59.

16 Idem. 
of police forces with military status in peace-keeping missions is also related to their dual dependency and thus their interoperability."17

- “As internal and external security agendas, or the realms of crime and war, continue to converge ... it can be assumed that gendarmerie or paramilitary forces will further gain in importance in years to come." 18

- "As the rise of gendarmeries points to a convergence or de-differentiation of police and military functions and thus a reversal of one of the major achievements of the modern nation-state, this development also raises important political and ethical questions which have to be addressed in the years to come." 19

In his dissertation, Lutterbeck concludes that, during the 1990s, there was a trend towards semi-military border policing, in many cases involving the gendarme forces, while the task of border policing was deepened to include not only the border itself, but "inward and beyond the line" as well, representing "a shift from line to space and flow." ${ }^{20}$ With the exception of methodology and further elaboration, the introduction of the concept of "deepening" of border control is the only significant difference between Lutterbeck's article and his doctoral thesis. ${ }^{21}$

\section{The Royal Marechaussee}

Lutterbeck selected his cases by choosing countries within the European Union with the most problematic outer borders (that is, with non-EU neighbors), those sharing borders with countries in and outside of the EU-enlargement agenda, those with both maritime and land borders, and those facing diverse cross-border challenges. How does the development of the Royal Marechaussee compare to descriptions in the international literature on gendarme forces, and particularly with Lutterbeck's analysis? Which ideas are supported, which do not apply, and which significant elements from the Dutch case are missing in the literature?

A number of general remarks can be made with regard to Lutterbeck's assertion that gendarme forces have acquired additional personnel and equipment for border patrol and international peacekeeping. First, the Netherlands was not among the cases that Lutterbeck addressed, probably because it has no external EU borders and because it shares no borders with countries on or outside the EU enlargement agenda. Although this is true from a classical, geographical perspective, it neglects the fact that many trans-border security challenges arise at harbors and airports. The Netherlands has one of the busiest ports in the world (Rotterdam) and the fourth-largest airport in Europe

17 Ibid., 62.

18 Ibid., 63.

19 Ibid., 64.

20 Derek Lutterbeck, The Fortress Walls: Policing the EU's External Borders, 1990-2001 (Geneva: Graduate Institute of International Studies, University of Geneva, 2003), 27-28.

21 Ibid., 208-12. 
(Schiphol Amsterdam). The Dutch border is also the outer border of the EU/Schengen Agreement region for passengers and goods that enter there.

Second, although Lutterbeck makes no mention of other tasks, gendarme forces in Europe have many other tasks in addition to border patrol and international operations. Policing the military is another traditional domain of gendarme forces. This task became less significant with the downsizing of Western defense forces after the end of the Cold War. Any growth in the size of the gendarmerie is therefore likely to reflect growth in other tasks that compensated for the many jobs that were lost when the task of policing the military was relinquished.

Third, Lutterbeck describes the growth of gendarme forces, but fails to relate these developments consistently and thoroughly to the development (number of personnel and budget) of the rest of the military and all civilian police services. In the case of Germany, Lutterbeck compares the budgets of the Bundesgrenzschutz and the military, as well as the personnel numbers of the Bundesgrenzschutz and the Länder police forces. ${ }^{22}$ For Austria, he makes similar comparisons between the Federal Gendarmerie and the Federal Police and between the Federal Gendarmerie and the military. ${ }^{23}$ In Spain, the comparisons he draws are between the Guardia Civil and the National Police, and between the Guardia Civil and the military. ${ }^{24}$ For Hungary and Poland, however, all three aspects were used for comparisons between the Border Guard, police, and armed forces. ${ }^{25}$ For Italy, Lutterbeck states that the Navy was downsized by 30 percent while the Coast Guard doubled in size, but he fails to mention the criteria that were used for this comparison. With regard to budget, he compares the Guardia di Finanza, the State Police, the Carabinieri and the military. ${ }^{26}$

Fourth, Lutterbeck's comparisons are limited to a fifteen-year period beginning in the early 1990s. This makes more sense for a project based in the perspective of international relations (the end of the Cold War) than in the framework of domestic security. Lutterbeck fails to put the presumed rise of these forces into the context of developments in domestic security. In the 1970s, the relatively calm period that had come about with the end of the Second World War came to an end, and criminality and public disorder grew significantly in many Western European nations.

Fifth, Lutterbeck presents no statistics on the numerical growth of the peacekeeping tasks taken on by individual gendarme forces. He elaborates only on the international significance of gendarme forces for these operations. Although he mentions the police contributions of many countries' UN operations, he fails to list the number of gendarmes that were actually sent abroad. The significance of this task for the gendarmes remains open to question. Furthermore, Lutterbeck does not examine the numerical development of other tasks of the gendarmes.

\footnotetext{
22 Ibid., 40.

23 Ibid., 82.

24 Ibid., 179-80.

25 Ibid., 191.

26 Ibid., 130, 142-43.
} 
In the following sections, I analyze the development of the Royal Marechaussee, including aspects of its work that were omitted by Lutterbeck in his study of other European gendarmerie organizations. First, I compare the growth of the Royal Marechaussee to the numerical development of other police organizations and the military in the Netherlands since 1970. These will be matched with population and economic growth. The second section focuses on the various tasks of the Royal Marechaussee, charting their development since the late 1980s. This information reveals that most of its growth can be explained by two new tasks: policing civilian airports and the mobile monitoring of aliens. The third section investigates the question of why tasks are assigned to the gendarmes by considering the new tasks that were assigned to the Dutch gendarmerie. How and why did the Royal Marechaussee acquire responsibility for policing airports? Why did it acquire responsibility for the mobile monitoring of aliens when the Netherlands stopped patrolling its eastern border as a result of the Schengen Treaty? The fourth section is devoted to international police missions. It compares the significance of this task to the Dutch civilian police, the Royal Marechaussee, and the military. I also discuss how the Royal Marechaussee's national tasks relate to its work in international peacekeeping operations.

\section{The Dutch Case in Numbers}

The year 1970 provides an interesting starting point for our investigation. With the Cold War fully developed and post-war internal security having stabilized, Western European countries encountered several waves of internal and external security developments. In the classical domain of the military, the 1970s were the era of détente and Vietnam, causing a major change in public attitudes towards the armed forces. Although the Cold War intensified during the 1980s, the decade ended with the disintegration of the Soviet bloc when the Berlin Wall came tumbling down. In the 1990s, the likelihood of full-scale war in Europe diminished, and the military became increasingly involved in expeditionary missions outside the NATO treaty area. Peace-support operations were carried out under the umbrella of the United Nations and NATO.

From 1970 onward, the internal security environment in Western countries like the Netherlands also changed significantly. ${ }^{27}$ The early 1970s saw the emergence of terrorism and other forms of political extremism. Although these problems receded in the 1980s and 1990s, they re-emerged in the early years of the twenty-first century, although they now originate from Islamist groups rather than from radical left-wing factions. Throughout the 1970s, leftist students challenged the political system. In the Netherlands, large squatter movements emerged. Both of these developments posed serious challenges to public order in larger urban areas. Drugs and immigration also emerged as serious sources of criminality during the 1970s.

All of these internal security issues continued well into the 1980s in the Netherlands, with only the squatters' issue being largely resolved. The early 1990s saw an in-

27 See Michael Wintle, "Policing the Liberal State in the Netherlands: The Historical Context of the Current Reorganization of the Dutch Police,” Policing and Society 6:3 (1996): 18197. 
crease in the pace of globalization, which had the unfavorable side effects of increasing illegal immigration and importing organized crime. Petty crime also rose significantly. In the late 1990s and the early 2000s, an increase in the number of minor public-order incidents and citizen harassment contributed to the problem.

What was the influence of these developments on the size and budgets of military and police organizations in Western countries? One would expect that the numbers and budgets of the military throughout Western Europe would have decreased since the early 1990s. Police organizations can be expected to have increased steadily since the early 1970s. The following section examines developments in the Netherlands in more detail.

Figure 1 shows the development of the absolute numbers of personnel of the Royal Marechaussee, the rest of the Dutch military, and Dutch civilian police organizations.

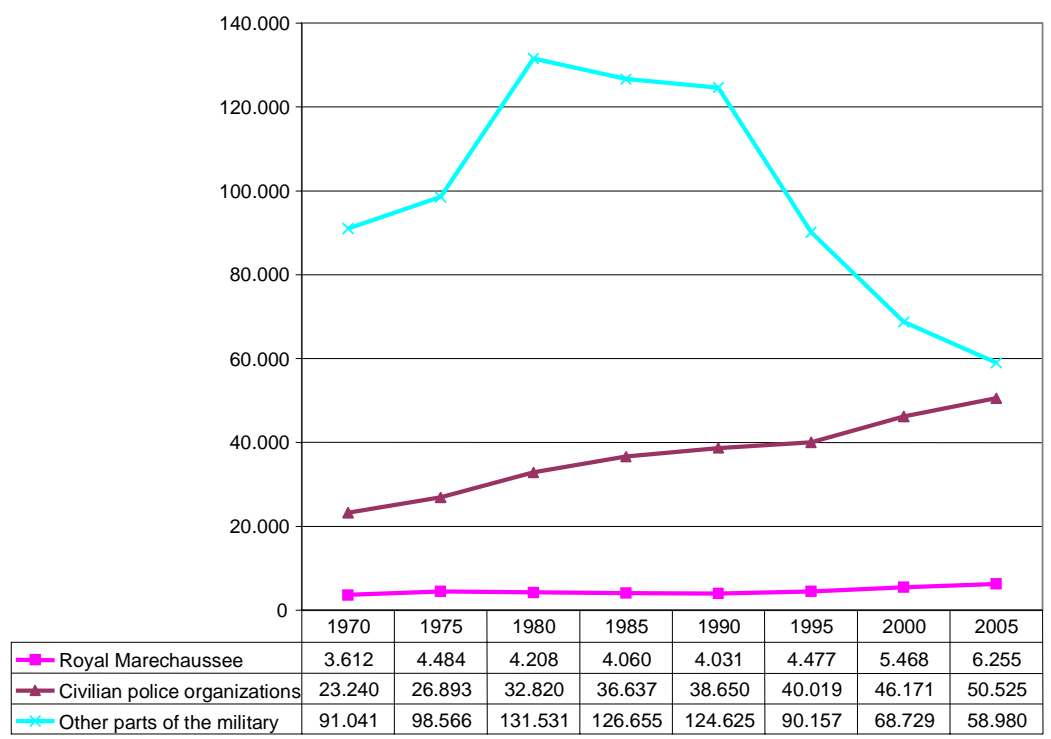

Figure 1: Security Forces’ Personnel Numbers. ${ }^{28}$

${ }^{28}$ Statistics drawn from Statistics Netherlands, annual budgets of the central government, annual reports from the KLPD, and the National Police Institute; N. Groeneweg and Anne Hallema, Van Nachtwacht Tot Computermacht: Vijftig Eeuwen Politie en Justitie (Zaltbommel: Europese Bibliotheek, 1976); and Frits Vlek, Hoe Sterk is de Politie: Een Internationaal Vergelijkend Onderzoek Naar de Omvang en Grondslagen van de Sterkte en Budgetten van de Politie in België, BRD/Nordrhein-Westfalen, BRD/Niedersachsen, Denemarken, Engeland+Wales en Nederland (The Hague: Ministerie Van Binnenlandse Zaken, 1994). Military personnel figures include civilian personnel. 


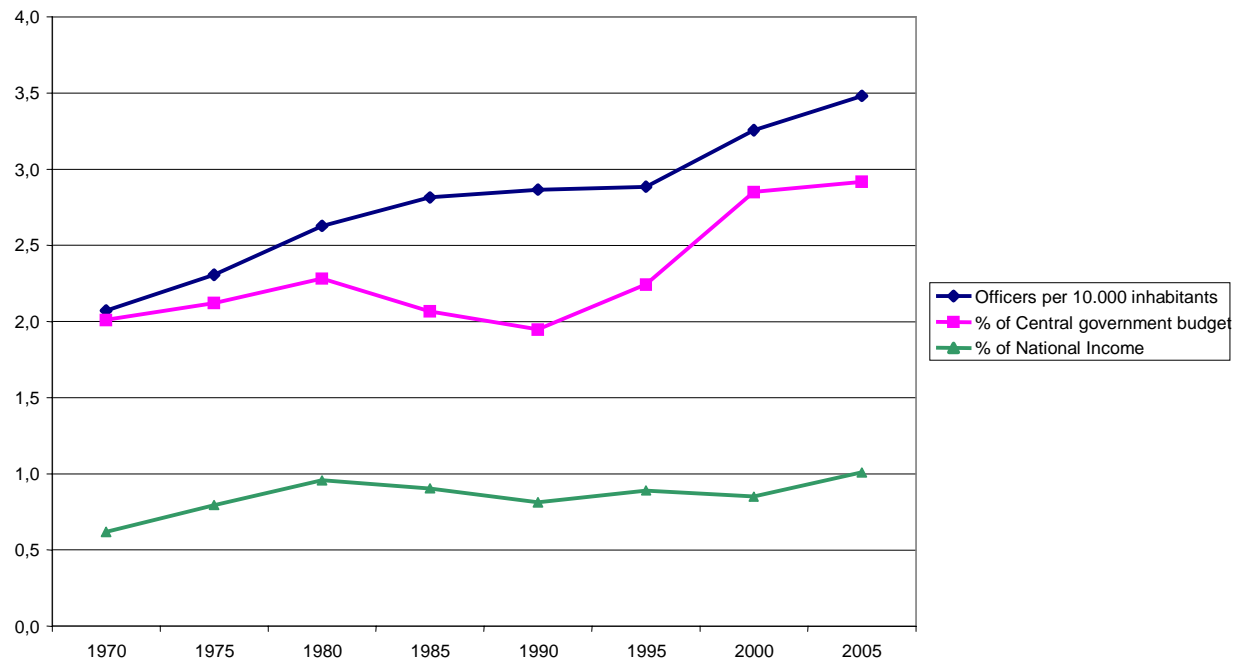

Figure 2: Development of the Dutch Police.

From Figure 1, we can conclude that the size of the Dutch military has decreased considerably since 1990, while the numbers of personnel in the civilian police have risen steadily since the early 1970s, as expected. ${ }^{29}$ While the former can be explained by the diminution in the military threat brought about by the end of the Cold War, the latter requires further consideration. The numerical strength of a country's police force is probably linked to the size of its population, wealth, central government spending, and internal security challenges. ${ }^{30}$ The first three factors are obviously easier to measure than is the fourth. Figure 2 shows the link between the size of the Dutch police and these three factors.

From Figure 2, we can conclude that the rate of growth of the Dutch police-civilian and military combined-did indeed exceed that of the population. Since the early 1970s, the budget for these services increased as a percentage of central government spending, with the cutbacks of the 1980s being completely undone between 1990 and 1995. They have been increasing ever since; the number of police officers did not de-

${ }^{29}$ Before the 1993 police reorganization, the Netherlands featured the nationally controlled Rijkspolitie and dozens of municipal Gemeentepolitie forces. These were replaced by the twenty-five regional Regiopolitie forces and the national Korps Landelijke Politie Diensten (KLPD).

${ }^{30}$ In the Netherlands, all police forces are paid from the central governmental budget. This currently applies to the regional police, as it had for the municipal police before the reorganization of 1993. 


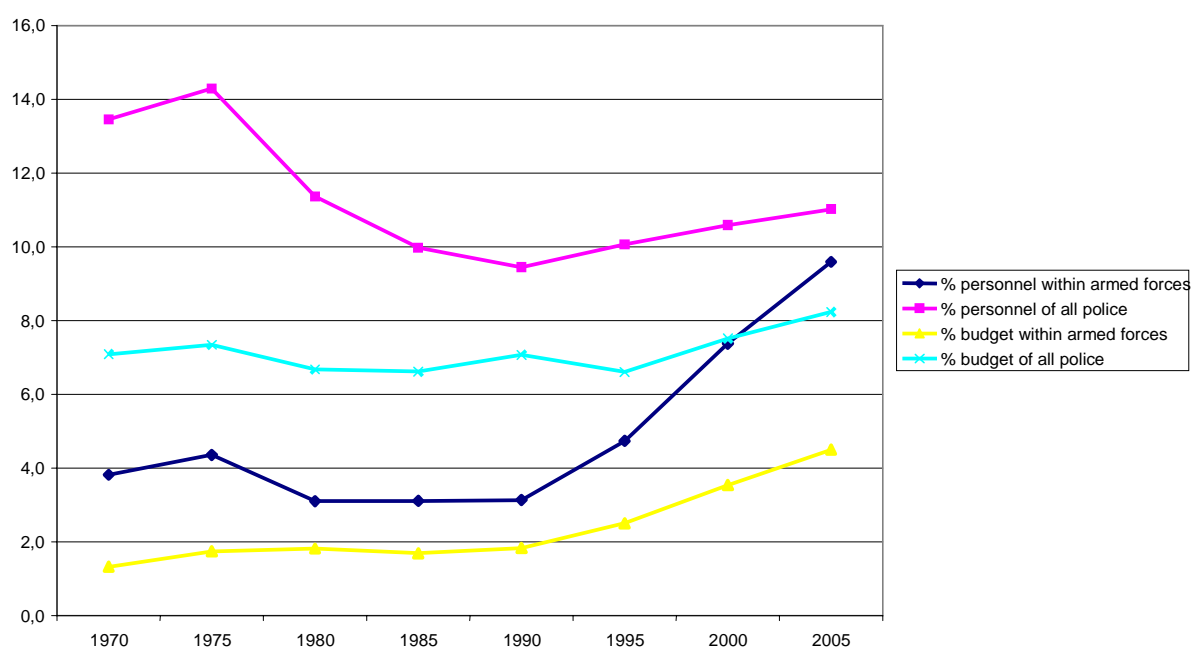

Figure 3: Royal Marechaussee between Police and Armed Forces. ${ }^{31}$

crease with the cutbacks. The police budget nearly doubled in the 1970s as a percentage of national income. After a period of decline throughout the 1980s, it has been increasing ever since.

In general, as could be expected from the increase in the number of internal security challenges facing nations in Western Europe (whether real or perceived), the police force in the Netherlands has expanded considerably since the 1960s. In this respect, the Dutch case is likely to resemble the experience of other Western European countries. But did the Royal Marechaussee (the Dutch gendarmerie) grow as Lutterbeck's conclusions would lead us expect? As shown in Figure 1, it did grow in absolute terms, but not as much as the civilian police did. The development of the intermediary position of the Royal Marechaussee is shown in Figure 3 in more detail.

As was suggested by Figure 1, Figure 3 shows more clearly that the Royal Marechaussee has become a far more important part of the Dutch armed forces since about 1990. Combining the personnel and budgetary growth of the former with the simultaneous significant reductions of the latter, the Royal Marechaussee doubled (budget) or tripled (personnel size) in relative importance. Before 1990, it had been a more stable factor within the Dutch armed forces. Relating the Royal Marechaussee to the size of the civilian police presents a different picture. The significance of the Marechaussee within the Dutch police system actually decreased between 1975 and 1990, although this trend has reversed dramatically since then. At present, however, it is less important than it was in 1970. This shows that Lutterbeck is correct about "the rise of the gendarmes," but that his theory only applies for the last fifteen years or so. At least in the

31 Military personnel figures include civilian personnel of the Ministry of Defense. 
Netherlands, the longer-term trend still seems to be that the armed forces, including the gendarmerie, are slowly being pushed to the sidelines of internal security matters.

Even with all of the above-mentioned changes, the budgets for these organizations are far more stable than the personnel percentages. One may question how the Royal Marechaussee managed to retain its proportion of the total police budget while its position in terms of personnel decreased. Another striking observation is that the size of the Marechaussee increased significantly during the 1990s. This increase occurred despite the downsizing of the Dutch armed forces (which decreased the number of personnel that were needed to police the military), the loss of conscripts in its own ranks, and the elimination of its task of patrolling the German border (Dutch-Belgian border controls had been eliminated in the 1970s).

What really happened in Holland? Does Lutterbeck's explanation for the rise of the gendarmes - increasing border patrol activities and participation in international policing operations (UN or NATO)—apply to the Royal Marechaussee?

\section{Tasks of the Royal Marechaussee}

A brief overview of the two centuries of history of the Royal Marechaussee seems to be useful here. Border control has traditionally been one of its three primary tasks, in addition to policing the military and assisting civilian authorities in managing public order and fighting crime in situations that exceeded the capacity of the civilian police. The Royal Marechaussee was the successor to the French gendarmerie. It was established in 1814 when the Netherlands regained independence after the Napoleonic occupation. The tasks of the Royal Marechaussee changed little until after the Second World War. Having experienced the horrors of the German occupation, including the militarization of the Dutch civilian police organizations, the Dutch government decided to place its police organization more firmly under civilian control than had been the case before the war. $^{32}$ It created a national civilian police force, the Rijkspolitie, which took precedence over the Royal Marechaussee (followed by the rest of the armed forces) to assist civilian authorities when the municipal police organizations were unable to handle security situations. Moreover, the Rijkspolitie acquired jurisdiction over many rural municipalities, including those located in border and garrison areas where the Royal Marechaussee was, in effect, the only police organization present, due to its tasks of controlling the border and policing the military.

This new position of the Royal Marechaussee at the periphery of Dutch police responsibility changed little until the 1970s. As described above, like many Western European countries, the Netherlands in the 1970s was faced with the first wave of new challenges to internal security: terrorism, political protests, drugs, and illegal immigration, as well as the uniquely Dutch phenomenon of squatters. In the 1970s and 1980s, the Royal Marechaussee assisted the civilian police on many occasions. It also ac-

32 Jos Smeets, De Geschiedenis van de Nederlandse Politie, Verdeeldheid en Eenheid in het Rijkspolitieapparaat (Amsterdam: Boom, 2007), 261-410. 


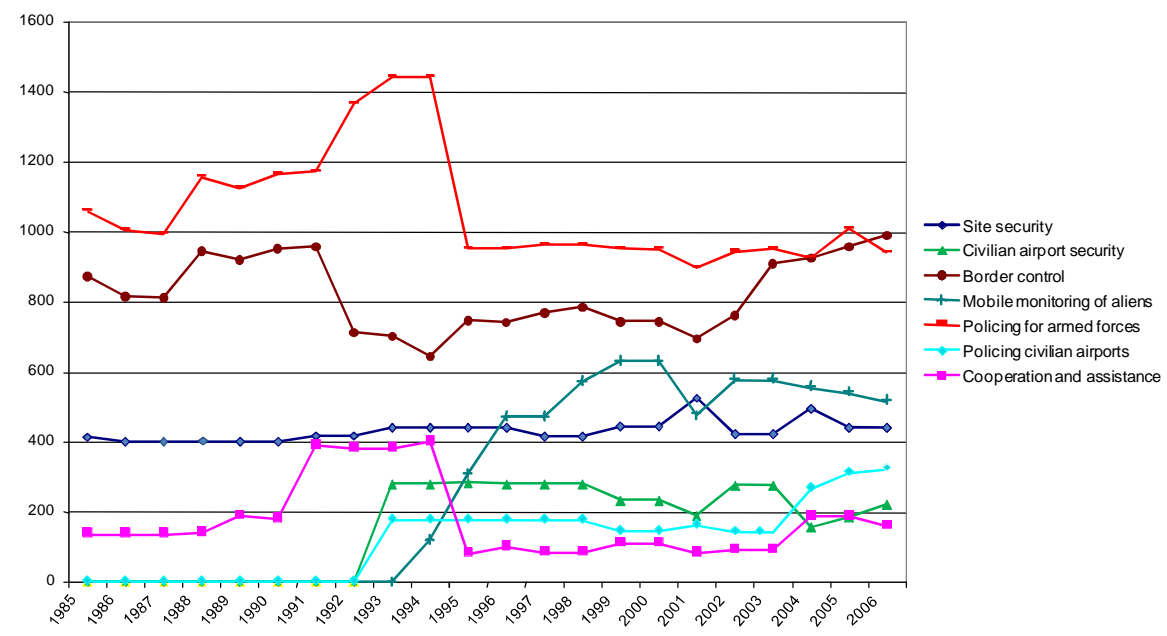

Figure 4: Development of Tasks of the Royal Marechaussee. ${ }^{33}$

quired a number of "semi-permanent" tasks: protecting diplomatic establishments, assisting municipal police forces in The Hague and Amsterdam, and protecting civilian aviation at Schiphol Amsterdam Airport.

What were the tasks of the Royal Marechaussee in the late 1980s? How many resources did it apply to each task? Most importantly, how have these tasks developed since then? Figure 4 shows the extent to which Lutterbeck's assertions linking the growth of gendarme forces to the growth of border control and international operations are applicable to the Netherlands. The figure lists all of the tasks to which the Royal Marechaussee assigned more than one hundred of its personnel on a regular basis. Peacekeeping is not among them. ${ }^{34}$

Four conclusions can be drawn from this body of data. First, policing the military lost much of its significance during the 1990s, as could be expected from the end of conscription and the cutbacks in various parts of the Dutch armed forces. Second, two new tasks-airport policing (consisting of more general policing activities and airport security, particularly for high-risk airline companies) and the mobile monitoring of aliens - can largely explain the growth of the Royal Marechaussee. These tasks pro-

33 Data drawn from budgets of the central government, planning documents, and statistics provided by the Royal Marechaussee.

${ }^{34}$ International operations involved fewer than one hundred officers; they are discussed in the next section. Site security consists of protecting military installations, the palaces of the royal family, and the home of the prime minister of the Netherlands. 
vided approximately one thousand new jobs, completely offsetting the loss of half of its capacity for policing the armed forces. To find personnel for these new tasks, the Royal Marechaussee apparently mobilized internal resources from groups dedicated to cooperation/assistance and border control. Third, although the border control unit did increase by between two hundred and four hundred individuals since the early 1990s, this increase cannot fully explain the growth of the entire organization by more than two thousand jobs, as depicted in Figure 1. This fact-particularly when considered alongside the fact that international operations occupied fewer than one hundred Dutch gendarmes-indicates that Lutterbeck's explanation for the rise of the gendarmes does not apply to the Netherlands.

Fourth, policing the armed forces (and providing security at military facilities) have become much less important tasks for the Royal Marechaussee relative to its other civilian tasks. Since the early 1990s, its identity has shifted away from that of the police organization responsible for the armed forces and border control toward being an organization that is oriented primarily toward the domains of domestic security and civilian policing. We can therefore assume that the rise of the gendarmes-and not just in the Netherlands-might also be related to domestic security too, instead of only to developments in external security (e.g., policing abroad and border control), as Lutterbeck suggests.

\section{Explanations for Two New Tasks}

To understand the rise of the gendarmes, it is very important to establish why new tasks have been assigned to them. Why did the Royal Marechaussee acquire the tasks that made it grow so spectacularly? ${ }^{35}$ First, I discuss alternative explanations for the involvement of military forces in internal security. I then describe how and why the Royal Marechaussee acquired the task of policing airports, and how it acquired the new task of conducting mobile monitoring of aliens. Finally, I return to the relationship between the gendarmes and internal security.

Literature from the Netherlands provides many explanations for decisions made since the Second World War whose effect has been to assign specific internal security tasks to the military instead of to civilian security organizations. Twelve explanations can be identified in this Dutch scholarship:

- The poor state of civilian alternatives to the military organization

- The fact that the national government has command over military units, while it can not command the (local) civilian police forces

- The attitude of military personnel is different from that of personnel in civilian security organizations

- The availability of military units, whether in terms of either structural capacity or the greater ability to send units to the scene quickly 
- Precedents for the performance of internal security tasks by the military

- The expertise of military units

- The fact that the military has more suitable equipment for this new task

- Administrative considerations, particularly with regard to relations between public organizations (e.g., maintaining central governmental control over executive organizations, financial considerations, preventing executive organizations from becoming large enough to dominate specific security domains)

- The political will to maintain the actual size of military units (especially with regard to the Royal Marechaussee as a strategic reserve to the civilian police)

- The fact that military units in general, and the Royal Marechaussee in particular, have both military and civilian tasks, meaning that they are best suited for tasks that fall between the traditional domains of the military and the police

- The exceptionality of the situations (internal security crises) that exceed the capacity of civilian organizations

- The positive attitude of the military leadership toward taking on more internal security tasks. ${ }^{36}$

Despite producing such an extensive list, the Dutch literature fails to explain why the Dutch government assigned extra internal security tasks to the military. The literature on this question is quite scant, and is often not scientific. My doctoral thesis was meant to fill this gap. It contained two case studies relevant to this article. I sought explanations for why the Royal Marechaussee was assigned the tasks of policing at civilian airports and mobile monitoring of aliens. Below I will describe the cases and the results of my research.

In the late 1980s Schiphol Amsterdam Airport was much smaller than it is now, and responsibility for security was held by the national Rijkspolitie. Several other security organizations were working at the airport as well, including the apparatus of the private company that operated the airport (along with a number of private security firms that it had contracted to assist); the customs service; private security firms assisting the Rijkspolitie; the municipal police of Haarlemmermeer; and the Royal Marechaussee. The Royal Marechaussee had two tasks: policing the border and assisting the Rijkspolitie. Since the early 1970s, the Royal Marechaussee had been providing extra security on board high-risk flights to and from Schiphol, and had been deploying heavily-armed teams to protect the activities of the airlines at the airport itself. By the late 1980s these tasks had begun to acquire an increasingly permanent character. Formally, these tasks fell under the category of assisting the Rijkspolitie. After two decades,

35 This section is based on my doctoral thesis on the internal security tasks of the Dutch armed forces. See Michiel de Weger, De Binnenlandse Veiligheidstaken van de Nederlandse Krijgsmacht (Assen: Van Gorcum, 2006); includes summary in English. Ibid. 
however, the task of protecting civilian airlines was increasingly regarded as one of the Royal Marechaussee's own tasks.

The option to assign responsibility for all policing at Schiphol-and five other civilian airports - to the Royal Marechaussee first emerged in the late 1980s, and it became a topic of increasing discussion in government. Three factors contributed to the likelihood that the Royal Marechaussee would get the task it wanted.

First, the government was pushing for cutbacks in public-sector spending. Reducing the number of security organizations operating at Schiphol would reduce overhead. Transferring border-policing responsibility to the Rijkspolitie was considered a less viable option than transferring all other policing responsibilities at airports to the Royal Marechaussee.

A second, more important factor was the threat of significant personnel reductions at the Royal Marechaussee due to radical cutbacks in the size of the Dutch armed forces after the end of the Cold War, which subsequently reduced the number of personnel that the Royal Marechaussee needed for policing the military. Conscription had ended in all branches of the military, including the Royal Marechaussee. In addition, the Royal Marechaussee was about to relinquish all its policing tasks at the DutchGerman border because of the Schengen Treaty. In government, there was rather broad consensus that the size of the Royal Marechaussee should be maintained, in order to preserve its value as a strategic reserve of the central government during crisis. The Royal Marechaussee had proven its value in the 1980s - e.g., during squatters' riots, by controlling illegal immigration, and by its role in protecting against terrorist and other extremist actions on diplomatic premises and at Schiphol. The Dutch government was actively considering a host of possible new tasks for the Royal Marechaussee, including policing at Schiphol.

A third factor can also help to explain why the latter option was chosen. The $G e$ meentepolitie and Rijkspolitie were to be reorganized into regional police organizations (which would fall under the control of the mayors and the Public Prosecution Service), and a national police-services organization (Korps Landelijke Politiediensten or KLPD), which would be controlled by the central government (Ministry of Justice). ${ }^{37}$ Most importantly, the mayors had negotiated that the KLPD would have no executive policing tasks, thus representing no competition for the regional police forces. This meant that the national government had three options:

- Responsibility for policing at Schiphol would be assigned to one of the newly formed regional police forces

- Schiphol would be assigned to KLPD, and thereby form an exception within the design of the new police system

- $\quad$ The Royal Marechaussee would step in.

The two regional police organizations adjacent to Schiphol were Amsterdam-Amstelland and Kennemerland. The latter was considered too small and "provincial” to

37 Control was transferred to the Ministry of the Interior some years later. 
handle affairs at the rapidly growing airport. In contrast, Amsterdam-Amstelland was likely to become too dominant among the regional police organizations were it to acquire responsibility for policing at the airport. Although the Amsterdam municipal government lobbied heavily for this option, the cabinet rejected it. The Ministry of Defense, the Royal Marechaussee, and the Ministry of the Interior pressured the Ministry of Justice to opt for handing responsibility for airport policing from the Rijkspolitie to the Royal Marechaussee. The Minister of Justice, who was then still responsible for the Rijkspolitie, eventually took the defensive step of choosing the Royal Marechaussee. Rather than having to share control over airport policing with the Ministry of the Interior (which would have placed it in the hands of the KLPD), he chose to transfer the task to the Royal Marechaussee, which he could control directly. When the Ministry of Defense promised to cover the additional cost of the expected personnel increases that the Royal Marechaussee would need for policing the rapidly growing airport, the Ministry of Justice also gained financially from the decision.

A few years later, in 1994, the Dutch government decided rather suddenly to assign another "new" task to the Royal Marechaussee: mobile monitoring of aliens. With national parliamentary elections only a few months away, the cabinet, which was led by the Christian Democrats, took dramatic steps to curb the inflow of illegal immigrants fleeing conflict situations, primarily in the Balkans, Iraq, and Somalia. Because the Schengen Treaty had lifted all formal border controls along the long Dutch-German border (the Benelux Treaties had suspended controls along the Belgian border in the mid-1970s), the government desperately wanted action. The Royal Marechaussee proposed a solution: it would form mobile units to check the passports and immigration documents of aliens in areas directly inside the border. The proposal stated that the Marechaussee could have five hundred officers in the field within months. Cutbacks in military policing and the abandonment of all posts at the eastern border assured the availability of the personnel that they needed to make this offer. The cabinet accepted the proposal within one week. These two factors - time pressure and the availability of resources-explain why the task was assigned to the Royal Marechaussee.

In one sense, the mobile monitoring of aliens was not a new task, but rather an extension of their responsibility for border control. In Lutterbeck's terminology, it represented a "deepening" of border control. In another sense, however, it was indeed an entirely new type of activity.

First, although the work itself-checking the passports of aliens-was not new to the officers of the Royal Marechaussee, the border-control posts had been abandoned. The task would now be performed between the border and the first Dutch highway approach or train station. Instead of fixed posts, mobile teams would choose the sites for controlling border traffic. Second, the mobile monitoring of aliens was also a new task in that its initiation required a cabinet decision. The effects of the Schengen Treaty, including the scaling down of Royal Marechaussee operations, had been discussed in parliament since the late 1980s. Many other tasks for the Royal Marechaussee that could replace their deployment on border control operations had been discussed. As early as 1988, the legislature had suggested the possibility of introducing "flying brigades." Third, after the border-patrol posts were closed in 1991, the two hundred 
Marechaussee personnel that had previously staffed these posts were reassigned to work for local, civilian immigration police services in several Dutch cities for three years. This was regarded by many as a new task that the Royal Marechaussee would ideally perform for a long time, and one that could become a regular task in its own right, rather than remaining an auxiliary to the civilian police. After the cabinet made the decision to start mobile monitoring of aliens, the Royal Marechaussee even tried to merge these activities with its new task, but these attempts failed for financial reasons. The two hundred officers were withdrawn. The decision to award responsibility for mobile monitoring of aliens to the Royal Marechaussee met with as much applause as surprise in the legislature. There is another sense in which this shift was something new. Finally, these two tasks-border patrol and mobile monitoring of aliens-were mentioned as separate, distinct activities by the Ministry of Justice, the Ministry of Defense, and the Royal Marechaussee in both internal documents and external publications.

Another factor that can explain why the Royal Marechaussee acquired the task of the mobile monitoring of aliens is related to its position in the Dutch police system. The government had also awarded five hundred extra officer positions to the regional police organizations in border areas. These officers were to monitor aliens residing within their municipalities. Although the government could have assigned mobile monitoring to the regional police forces as well, it did not do so, for fear that local authorities would later assign the additional officers for it to other tasks. The central government, however, could exercise direct control over the Royal Marechaussee, ensuring that alien controls would remain a top priority - an option that proved more attractive. To be precise, responsibility for monitoring aliens rested with the Ministry of Justice. As in the Schiphol case that was discussed above, the Ministry stood to gain more by transferring the task to the Royal Marechaussee than it did by transferring it to the regional police forces, which were controlled by the mayors and which were indirectly on the payroll of the Ministry of the Interior.

In summary, there are five explanations for why the Royal Marechaussee acquired its two most valuable (in terms of personnel growth) tasks:

- Financial considerations

- The desire to maintain the Royal Marechaussee at a sufficient size

- The desire to ensure central governmental control

- $\quad$ Time pressure to begin mobile monitoring of aliens

- The availability of readily deployed resources.

My Ph.D. thesis examined three additional cases in which new internal security tasks were transferred to the military: the creation of the military National Reserve in 1948, the transfer of responsibility for conventional and improvised/terrorist explosives ordnance to the military, and the creation of military anti-terrorist/SWAT teams. Two dominant explanations emerged from all of these cases: the military acquired these tasks because they had personnel available and because these personnel could be controlled directly by the central government. These explanations are consistent with 
the conclusions that can be drawn from the cases regarding airport policing and the mobile monitoring of aliens.

Most important for this essay, there are many explanations for the growth of the Royal Marechaussee. It is too superficial to simply point at the proliferation of its tasks; any explanation of the rise of gendarmes must also involve an analysis of how they acquired these tasks in the first place. These decision-making processes are often probably more a result of internal security circumstances, political and administrative processes, and competition with civilian police forces than they are a product of international developments. An awareness of this element is largely missing in Lutterbeck's analysis.

\section{International Operations}

This section is devoted to international operations. Lutterbeck states that international peacekeeping missions represent the second main growth area for Europe's gendarmes. This section investigates the accuracy of this claim and examines the significance of this task to the Royal Marechaussee. I will begin with my conclusion: international operations cannot account for a significant portion of the more than two thousand personnel that were added to the Royal Marechaussee since the early 1990s.

Sterrenburg lists the number of full-time equivalents the Royal Marechaussee and Dutch civilian police sent abroad for policing tasks between 1989 and 2002. ${ }^{38}$ The Royal Marechaussee sent personnel to eleven missions. ${ }^{39}$ Sterrenburg estimates that these operations involved 839 full-time equivalents, at an average of 60 per year. Between 1995 and 2001, the Dutch civilian police sent 42 full-time equivalents abroad, at an average of six per year. ${ }^{40}$ In 2003, the Dutch government decided to make one percent of all police personnel (270 persons) available for international policing operations: 240 from the Royal Marechaussee, and 40 from the civilian police.

As was shown in Figure 4 above, the Royal Marechaussee has never sent more than 120 of its personnel abroad in any year since $2002 .{ }^{41}$ The Dutch civilian police services have sent even less, while the rest of the Dutch military has sent up to 2,500 of its personnel each year during the last decade. The relatively low numbers sent by the civilian police (40 out of approximately 50,000 civilian police officers in the Netherlands) can be explained by the fact that it is harder to mobilize civilian police officers than military police personnel and that, inside the civilian police culture, participating in such

38 Hermen Sterrenburg, Internationale Vredesmissies en de Nederlandse Politie: Een Verkenning Rond Beheer en Sturing (Apeldoorn: Nederlandse Politie Academie, 2002). UNTAG/South Africa, UNAVEM-Angola, UNTAC-Cambodia, the WEU-Danube-mission, UNOMSA-South Africa, UNOMOR-Uganda/Rwanda, UPFM-Mostar, UNIPTF-BosniaHerzegovina, UNMIK-Kosovo, MAPE-Albania, and ECPA-Albania.

40 Sterrenburg, "Internationale Vredesmissies," Annexes 3 and 6. Personnel to support the UN's Rwanda and Yugoslavia tribunals, the South African police and Truth Commission, the Red Cross in Brazil and Macedonia, OSCE-Kosovo, and ECPA-Albania.

41 Although the Minister of Defense reported to Parliament in 1999 that the Royal Marechaussee had sent an average of 160 personnel abroad per year for peacekeeping missions (Tweede Kamer, vergaderjaar 1999-2000, 26900, nrs. 1-2, 169). 
missions is less rewarding in terms of career opportunities than it is in the military. ${ }^{42}$ The Royal Marechaussee is also better trained and equipped for this type of operation than are civilian police forces; it has more experience in international environments, and usually accompanies the Dutch military in operations abroad. Nevertheless, it has yet to deliver the 240 officers abroad that the government hopes to see. The Royal Marechaussee is now creating a pool of about 200 officers especially for peacekeeping missions. The international shortage of police officers for UN and NATO operations offers an excellent opportunity for the Royal Marechaussee to deploy more officers in the coming years than it has thus far. ${ }^{43}$ Even if the Royal Marechaussee were to deploy 200 officers, it would still be deploying less, proportional to its size, than the rest of the Dutch military. The deployment of 300 would even this balance.

How do the domestic tasks of the Royal Marechaussee compare with its activities abroad? Most operations abroad have involved policing the Dutch military, which is

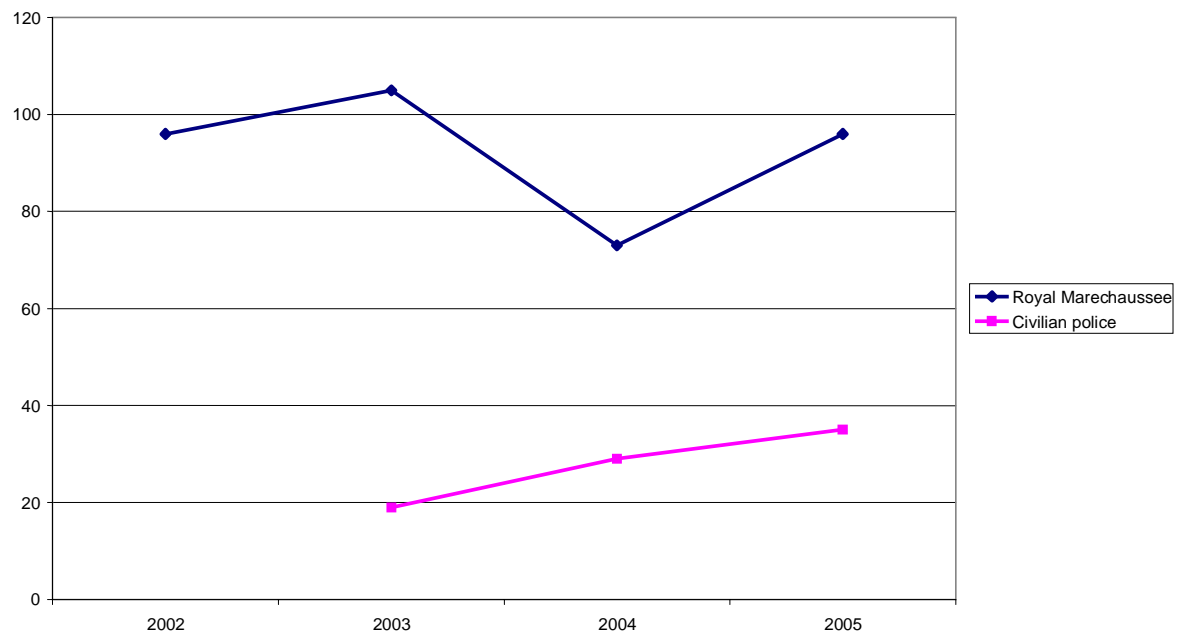

Figure 5: International Policing Operations. ${ }^{44}$

${ }^{42}$ N. van Delft, "Internationaal Politiewerk: Een Bijzondere Ervaring, Die Niet Altijd Wordt Gewaardeerd,” Algemeen Politie Blad 12 (2005): 10-11.

${ }^{43}$ On the shortage of officers see Hans Hovens, "Policing at the Threshold," Paper for LIPO III (Maastricht: Nederlands Beveiligings Bureau, 2005); Alice Hills, "The Inherent Limits of Military Forces in Policing Peace Operations," International Peacekeeping 8:3 (Autumn 2001): 79-98; and Oakley, et al., Policing the New World Disorder.

Statistics provided by the Royal Marechaussee and the Centre for Strategic Studies, Clingendael. 
essentially equivalent to the task that it performs at home. ${ }^{45}$ With regard to the other operations, most involve training or advising local police; neither of these tasks is performed domestically. ${ }^{46}$ In only a few cases did the Royal Marechaussee actually perform executive police tasks similar to those that it performs in the Netherlands. In UNMIK-Kosovo, it maintained public order. In the PCOD-Donau operation, it served as a border police force to uphold the UN embargo. Border patrol was also a task during MFO in Sinai. It is therefore fair to conclude that the Royal Marechaussee has not applied much of the expertise that it has acquired from its various tasks in the Netherlands to its peacekeeping and CIVPOL-operations abroad. Has the Dutch gendarme not made use of opportunities in this field, as Lutterbeck claims other gendarmes have?

\section{Reflection on Hypotheses}

What does the case of the Royal Marechaussee tell us about other hypotheses of Lutterbeck and the comments of other authors regarding the function and historical development of gendarme forces? The conclusions of my own doctoral research support Janowitz's thesis that gendarmes and other military forces are primarily instruments of the central government. The other dominant explanation for the transfer of internal security tasks, however, is that the military sometimes has sufficient personnel available on short notice to handle such internal security challenges as "unrest and mob action." With regard to Janowitz's “continuous task of policing the potentially disruptive groupings of resistance or opposition to the central regime - regional, religious, or ethnic minorities who feel excluded from the existing political arrangements," this has not been a task of the Royal Marechaussee for a very long time. Fortunately, the Netherlands has not been confronted by significant resistance or opposition requiring military action on behalf of the central government. Although the protests and violence of the squatters and South Moluccans in the 1970s were severe infringements on public order and the rule of law, they were local, relatively rare, and geographically dispersed. They certainly did not amount to uprisings, revolts, attempts at revolution or coups d'état, nor did they result in resistance movements or the rise of rebellious or lawless regions.

The history of the gendarmerie in the Netherlands offers support for Deflem's thesis that police institutions, including military police, tend to become aligned with the

45 This was the Royal Marechaussee's mission in: UNMIS-Sudan, KFOR-Kosovo, PRT-Afghanistan, Enduring Freedom-Afghanistan, NATO Training Mission-Iraq, EUFOR-Bosnia, SFIR-Iraq, UNMIL-Liberia, Task Force Fox-Macedonia, Enduring Freedom-Qatar, ISAFAfghanistan, UNMEE-Djibouti, Ethiopia and Eritrea, Task Force Harvest-Macedonia, KFOR-Kosovo, Allied Force-Albania, UNIFCYP-Cyprus, SFOR-Bosnia, EFOR-Macedonia, IFOR-former Yugoslavia, Deny Flight-Italy, UNMO-Bosnia, UNPROFOR-former Yugoslavia, Provide Comfort-Iraq, Desert Storm-Iraq, and MFO-Sinai.

These missions include EUBAM-Israel, EUBAM-Rafah/Gaza, EUPM-II-Bosnia, Monitoring-Aceh/Indonesia, EUPOL Kinshasa/ DR Congo, Proxima-Macedonia, NATO Training Mission-Iraq, EUFOR/IPU-Bosnia, EUPM 1-Bosnia, OSCE-Macedonia, ISAF-Afghanistan, ECPA-Albania, MAPE-Albania, UNIPTF-Bosnia, WEU-Mostar, UNMIH-Haiti, UNOMSASouth-Africa, UNTAC-Cambodia, UNAVEM-Angola, and UNTAG-Namibia. 
military during periods of war. The only war in which the Netherlands has been involved for the last two centuries (since the Belgian war of secession from the Netherlands) was the Second World War. Although it had hoped to remain neutral, as it had during the First World War, the Netherlands was occupied by the German armed forces after five days of fighting. For the Dutch there was therefore simply no time to realign the police with the military; during the military occupation, however, the Germans did overhaul the Dutch police system, making sure that they would be able to control it. This might not be what Deflem had in mind, but it does support his theory.

The case of the Netherlands does not offer an appropriate test for Hills's hypothesis concerning police forces during low-intensity conflicts, as there has not been such a conflict for centuries. On the contrary, the absence of low-intensity conflict does offer support for Schmidl. The Royal Marechaussee is a fine example of a gendarme force that should be regarded as a police force rather than as a true gendarmerie/paramilitary unit, as no significant, geographically concentrated, or protracted lawlessness or public unrest has existed in the Netherlands for at least a century.

The Dutch case offers support for some of Lutterbeck's eight other hypotheses concerning the development of gendarme forces, while it contradicts others. First, the military has not been removed from "the state's domestic sphere.” The involvement of the other parts of the military in internal security is currently rather rare. The Royal Marechaussee, however, has not been removed at all. Rather, it has experienced a comeback since the early 1990s. Second, its task of policing the military-both at home and abroad-has expanded slightly in terms of personnel, but it now constitutes a far smaller portion of its work in relative terms. At least in this sense, then, it has demilitarized. Its links to the armed forces have not been severed, however, thereby falsifying this hypothesis of Lutterbeck. Third, the fact that the Royal Marechaussee lost its rural tasks makes it an atypical gendarme force. With its tasks of assisting civilian authorities, protecting civilian aviation, and contributing to anti-terrorist squads, it does, in the words of Lutterbeck, have tasks "which are characterised by a higher degree of hostility or 'instability' than 'ordinary' policing usually involves.” Contrary to Lutterbeck, public and political opinion does not associate these with authoritarian or repressive tendencies, nor does it see them as potential threats to civil liberties. Fourth, Lutterbeck's hypothesis that the growth of gendarme forces is due to transnational challenges is at least partially true for the Royal Marechaussee (policing at airports, mobile monitoring of aliens).

The remainder of Lutterbeck's hypotheses can neither be falsified nor proven. The Dutch case involved no expansion of the gendarmerie with airplanes, helicopters, or high-speed patrol boats. The Royal Marechaussee has had two ships for border patrol for decades, and it has no aircraft. As indicated above, the Dutch gendarmerie has yet to become "popular" to deploy abroad, because of its "dual dependency and thus ... interoperability.” Finally, whether the Royal Marechaussee will become more important in the years to come remains to be seen, as do the important political and ethical questions that such gains could raise. 


\section{Conclusion}

What can be concluded from the discussion above? What does the Dutch case tell us about the development of gendarme forces? Four factors are likely to be dominant in determining the future of the Royal Marechaussee and similar gendarme forces. First, the regular police force is still engaged in the process of emancipating from the military. Because it was created as an alternative, and because it continues to increase in relative strength, there is less need for the military — and gendarmes in particular- to be involved in more regular policing. Second, the development of internal security determines the size of both the gendarmerie and the police. Since the 1990s, anxieties about terrorism and immigration/border control have driven the rise of the gendarmes. Were these issues to fade away, the gendarmerie could be downsized. Because it is an instrument of the central government, the gendarmerie might be directed toward solving new challenges for those that control it. Were internal security challenges within the realm of the regular police to diminish further, civilian police would have more "spare” capacity, allowing further emancipation. ${ }^{47}$ Third, political preferences for civilian police might result in "strategic demilitarization" of the gendarmes, overhauling their status as a part of the military and transferring them to civilian control. For longer than fifty years, no country in the Western world seems to have created a military police organization with regular police tasks. On the contrary, the Belgian gendarmerie (Rijkswacht) was removed from the military in the 1990s. With the increasing centralization of the civilian police systems in Europe, gendarme forces (or parts thereof) could be included in larger reorganizations of police systems. Fourth, future developments will also depend on the interests of the gendarmerie and on public opinion regarding how this force should be used. For countries like the Netherlands, civilian police forces are inadequate for missions that involved deploying larger numbers of police officers abroad for executive policing or for supporting local police with training, advice, or monitoring. If the demand for these activities increases, the gendarmerie is likely to benefit by gaining personnel (if necessary) to fulfill these tasks. If regular military units do not have higher priorities, they might take on some of the tasks of policing, not allowing much expansion of the gendarmerie. On the contrary, if gendarme forces are too consumed with internal security tasks in the home country to be involved abroad in any substantial way, the rest of the military might come to see them as a nuisance within the organization, and they might allow (or even promote) the strategic demilitarization of the gendarmerie.

Let me conclude by suggesting some topics for further research. It would obviously be interesting to learn more about why the gendarme forces of other countries are gaining or losing ground in internal security and international operations. Another fruitful direction would involve further study into the development of the tasks of the military or civilian police in countries that have no gendarmerie. What determines the

47 The Dutch Central Bureau of Statistics reports an increase in the number of registered crimes between $1996(1,189,217)$ to a peak in $2002(1,422,863)$, decreasing again in 2003 and 2004 $(1,324,608)$. 
development of police and military and their division of labor in the ever-changing security environment? Which units are better at which tasks? What can they learn from each other? Which will become less relevant in the years ahead? Will they merge, as some predict? ${ }^{48}$ In general, I would welcome further international comparisons between police systems. Useful comparisons would include the role of gendarme forces, other paramilitary organizations, agencies and squads with combined police-military origins, and semi-police organizations (e.g., the customs service, the Coast Guard, and immigration authorities). In addition to theoretical work, quantitative research could shed more light on their development - as the discussion above should clearly indicate. Perhaps because they are a part of the military, less is also known about the actual operations, concepts, performance, and policies of gendarme forces than is known about other types of police entities. They are apparently better able to evade public, scientific, and political scrutiny than are regular police forces. Paramilitary organizations seem to have been overlooked in both military and police research.

${ }^{48}$ Martin van Creveld, The Rise and Decline of the State (Cambridge: Cambridge University Press, 1999). 
WINTER 2008

\section{Bibliography}

Adams, David. "Internal Military Intervention in the United States." Journal of Peace Research 32, no. 2 (1995): 197-211.

Auten, James H.. The Paramilitary Model of Police and Police Professionalism In Police Studies 4., 1981.

Bayley, David H.. "The Police and Political Development in Europe." In The Formation of National States in Western Europe, 328-79. Princeton, NJ: Princeton University Press, 1975.

de Weger, Michiel. De Binnenlandse Veiligheidstaken van de Nederlandse Krijgsmacht. Assen: Van Gorcum, 2006.

Deflem, Mathieu. Policing World Society: Historical Foundations of International Police Cooperation. Oxford: Oxford University Press, 2002.

Easton, Marleen. De Demilitarisering van de Rijkswacht. Brussels: VUB Press, 2001.

Emsley, Clive. Gendarmes and the State in Nineteenth-Century Europe. Oxford: Oxford University Press, 1999.

Emsley, Clive. Policing and its Context, 1750-1870. London: Macmillan, 1983.

Engdahl, David E.. "Soldiers, Riots, and Revolution: The Law and History of Military Troops." Iowa Law Review 57 57, no. 1 (1971): 1-73.

Fijnaut, Cyrille. Opdat de Macht een Toevlucht Zij?: Een Historische Studie van het Politieapparaat als een Politieke Instelling. Arnhem: Gouda Quint, 1979.

Groeneweg, N., and Anne Hallema. Van Nachtwacht Tot Computermacht: Vijftig Eeuwen Politie en Justitie. Zaltbommel: Europese Bibliotheek, 1976.

Haenel, Hubert, René Pichon, and Richard Lizurey. La Gendarmerie. Paris: Presses Universitaires, 1983.

Hills, Alice. "Policing, Enforcement and Low Intensity Conflict." Policing and Society 7, no. 4 (1997): 291-308.

Hills, Alice. "The Inherent Limits of Military Forces in Policing Peace Operations." Interna-tional Peacekeeping 8, no. 3 (2001).

Huberts, Leo W. J. C.. Blinde Vlekken in de Politiepraktijk en de Politiewetenschap Over Politie, Wetenschap, Macht, Beleid, Integriteit en Communicatie. Arnhem: Gouda Quint, 1998.

Janowitz, Morris. Military Institutions and Coercion in Developing Nations. Chicago: University of Chicago Press, 1977. 


\section{THE QUARTERLY JOURNAL}

Lutterbeck, Derek. "Between the Police and Military: The New Security Agenda and the Rise of the Gendarmeries." Cooperation and Conflict 39, no. 1 (2004): 45-68.

Lutterbeck, Derek. The Fortress Walls: Policing the EU's External Borders, 19902001. Geneva: Graduate Institute of International Studies, University of Geneva, 2003.

Meliala, Adrianus. "Police as Military: Indonesia's Experience." Policing: An International Journal of Police Strategies and Management 24, no. 3 (2001): 420-31.

Miller, William W.. Party Politics, Class Interest, and Reform of the Police 1829-56 In Police Studies., 1987.

Neisingh, Cees N. J.. "Zusterkorpsen van de Koninklijke Marechaussee." Armex (1998): 22-25.

Rawlings, Philip. "The Idea of Policing: A History." Policing and Society 5 (1995): 129-49.

Rowe, Peter J., and Christopher J. Whelan. Military Intervention in Democratic Societies. London: Croom Helm, 1985.

Schmidl, Erwin. "Police Functions in Police Operations." In Policing the New World Disorder: Peace Operations and Public Security, 40. Washington, D.C.: National Defense University Press, 1998.

Sigler, Robert T., and David J. King. "Colonial Policing and Control of Movements for Independence." Policing and Society 3 (1992): 13-22.

Sterrenburg, Hermen. Internationale Vredesmissies en de Nederlandse Politie: Een Verkenning Rond Beheer en Sturing. Apeldoorn: Nederlandse Politie Academie, 2002.

Van Creveld, Martin. The Rise and Decline of the State. Cambridge: Cambridge University Press, 1999.

van Delft, N.. "Internationaal Politiewerk: Een Bijzondere Ervaring, Die Niet Altijd Wordt Gewaardeerd." Algemeen Politie Blad 12 (2005): 10-11.

van den Hoek, W.. De Geschiedenis van het Wapen der Koninklijke Marechaussee. Buren: Museum der Koninklijke Marechaussee, 1990.

Watts, Larry L.. Whose Professionalism?: Separating the Institutional Roles of the Military and Police. Camberley: Conflict Studies Research Centre, 2001.

Wintle, Michael. "Policing the Liberal State in the Netherlands: The Historical Context of the Current Reorganization of the Dutch Police." Policing and Society 6, no. 3 (1996): 181-97. 